\title{
Evaluation of the Implementation of the Youth Care Health Service Program in the West Lingkar Health Center of Bengkulu City
}

\author{
Oktarianita*, Bintang Agustina Pratiwi, Henni Febriawati, Riska Yanuarti \\ Kesehatan Masyarakat, Fakutas IImu Kesehatan, Universitas Muhammadiyah Bengkulu \\ Jl. H. Adam Malik Km 8,5 Cempaka PermaiKota Bengkulu, Indonesia \\ *corresponding author, e-mail: oktarianita@umb.ac.id
}

Received: 29/04/2021; published; 21/08/21

\begin{abstract}
Abstrak
Background: One of the strategies to overcome adolescent problems is the formation of the Youth Care Health Service Program or Pelayanan Kesehatan Peduli Remaja (PKPR). PKPR itself is a health service program aimed at adolescents and is a forum for overcoming adolescent problems. This study aimed to analyze the implementation of the PKPR program in the working area of the West Lingkar Health Center. Method: This research was a qualitative descriptive study conducted in March-April 2021. The methods used were observation and indepth interviews with seven informants: the person in charge of the PKPR program, health workers, peer counselors, and youth participating in PKPR. Results: The results showed that the PKPR program was aligned with the 2014 standard guidelines. This research was done inside and outside the health center by collaborating with PKPR's person in charge and the health team based on the Decree of PKPR implementation. PKPR program is held in three schools in the working area of the West Lingkar Health Center and provides services such as health checks, counseling, and education about youth health. The peer counselor training subprogram has fulfilled the standard $10 \%$ of the target schools. PKPR is fully funded by the Special Operational Assistance or Bantuan Operasional Khusus (BOK) fund. Recording and reporting were done every two to three months to the public health office. Monitoring was reported during the activities, while the evaluation report is annual. This research discovered the availability of counseling rooms and related references about communication, information, and education books on PKPR. This research had collaborated with cross-sectors such as schools and the National Antinarcotics Agency. Conclusion: Implementation is under PKPR guidelines, but overall it was still not optimal. There was no regular socialization of PKPR, especially for youth who did not attend school.
\end{abstract}

Keywords: Implementation, PKPR, Youth

This is an open access article under the CC-BY-SA license.

\section{Introduction}

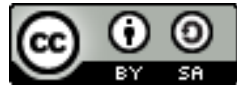

Adolescence is a developmental phase between childhood and adulthood where a person will experience many changes biologically, psychologically, and socially. Some of the adolescent problems, among others, are still high rates of smoking in adolescents, consuming alcohol, and health problems related to adolescent nutrition. Supported by Riskesdas data, 2018 showed that the number of smokers aged $10-18$ years reaches $5.3 \%$, adolescents consume alcohol (4\%), and adolescents experienced concise growth problems $(6.7 \%)[1]$.

Symptoms of depression indicated the prevalence of mental disorders at the age of $>15$ years $(6.1 \%)$, which was one of them caused by drug abuse [2]. Juvenile delinquency that has occurred recently is also part of uncontrolled adolescent psychic growth and 
development. The lack of supervision and assistance in daily life makes teenagers brave and try to make behavior to get attention. One of the environments that play a role in human life is the family. The family is the first place for a child to learn, especially those related to fulfilling basic human needs and adjusting to social life [3].

Juvenile delinquency is a behavioral deviation due to lack of parental attention/broken home, the influence of close friends, a social environment that is not good or too free, curiosity, and lack of religious knowledge. Smoking is one of the deviant behaviors hazardous to their health, especially the lungs, and drinking alcohol can interfere with their minds and consciousness [4].

Problems in adolescents require continuous and comprehensive handling by involving all elements from across related programs. The government created a program for Youth Care Health Services (PKPR). PKPR is a health service aimed at teenagers and can be attained by teenagers. PKPR has a pleasant impression, accepts adolescents with open arms, respects confidentiality and is sensitive to the health needs of adolescents, and is effective, efficient, and comprehensive in meeting these needs. The PKPR program is implemented, including counseling, educating, and coaching services for at least one target school for each health center [5].

The West Lingkar Health Center is one of the health centers that has been implementing the PKPR program since early 2010 in its building in counseling services. Then, in 2018 it was carried out outside the building in the form of counseling and school coaching with the formation of peer counselors. The initial observations also obtained information on PKPR activities for the West Lingkar Health Center work area, Bengkulu carried out in schools with participants were junior high school (SMP) and high school (SMA) children with an age range of 10-19 years.

The results of adolescent counseling activities 44 teenagers at one school stated: 30 teenagers had started smoking, 14 others experienced health problems such as obesity caused by lack of physical activity so that it interfered with the concentration of teenagers in learning, felt dizzy, and had vision problems because they were too busy, frequent use of gadgets, as well as the problem of adolescent reproductive disorders. It was also known that the program is carried out only by the Person in Charge of the PKPR himself. There is no management structure for the PKPR Program at the health center [6]. Researchers considered the results of observations made on problems that occur in adolescents to conduct research. Based on this background, the researchers analyzed the implementation of the PKPR program at the West Lingkar Health Center in Bengkulu City.

\section{Method}

This research was a qualitative descriptive study. This research focused on implementing the PKPR program at the West Lingkar Health Center, Bengkulu City. The research was carried out in the working area of the West Lingkar Health Center in Bengkulu City in March-April 2021. The data collection method used was observation techniques and in-depth interviews with sources of information related to the implementation of PKPR. The sources of information in this study were those involved in PKPR activities, namely: informant 1 (Mrs. S) as the person in charge of the PKPR program, informant 2 (Mrs. Df) as an officer in the field of nutrition, informant 3 (Mrs. El) as a health officer, informant 4 (Ms. P), and informant 5 (Ms. Re) were peer counselors registered as students of SMA Negeri 7, which was one of the target schools from the implementation of PKPR in the working area of the West Lingkar Health Center, and two people who become triangulation sources include triangulation 1 (Ms. Fv) and triangulation 2 (Ms. I) as PKPR participants at SMA Negeri 7. This study focused on implementing the PKPR program at the West Lingkar Health Center in Bengkulu City.

In-depth interviews were conducted based on the 2014 PKPR national standard reference, which met the aspects of PKPR implementation. The results and discussion in the study include Health Human Resources (HR), officer training, funding sources, implementation, PKPR services, recording, reporting, and evaluation of implementation. Data analysis by collecting data, analyzing results, discussing, and closing with conclusions.

\section{Results and Discussion}

\section{Disease Prevention and Public Health Journal}

Volume 15, Issue 2, September 2021: page 71-82 


\subsection{Results}

\subsubsection{PKPR Human Resources}

Based on the results of in-depth interviews regarding the human resources of the Youth Care Health Service (PKPR) program at the West Lingkar Health Center, West Lingkar Health Center has a team consisting of several health center officers with expertise in their respective fields and the person in charge of the PKPR program. However, the person in charge of PKPR stated that the staff was lack, especially in officers for this program. This problem was following the statement of the Person in Charge (PJ) of PKPR as follows:

"For the implementation, I am responsible for cooperating with health workers and cadres who have been trained previously. It is stated in the Decree (SK)" (Informant 1).

Supported by a statement from health officers (nutrition) that for the implementation of PKPR, they also participated in carrying out activities outside the building, as follows:

"For the implementation of PKPR, we help provide counseling to teenagers" (Informant 2).

"It is already in the team's decree" (Informant 3).

\subsubsection{Training of PKPR Officers}

The results showed that the training for PKPR staff had held, but only the person in charge of the PKPR program was participated in, while for other implementing officers, the training was generally given according to their respective fields. The training for peer counselors was conducted by coaching in schools. This training was following the statement of the person in charge of PKPR, as follows:

"We have held such PKPR training and we also have TB lung early detection training recently" (Informant 1).

"There is no PKPR training for us (officers). It is for PJ only. We are only in the field of expertise" (Informant 3.)

\subsubsection{Facilities and Infrastructure for PKPR Implementation}

The results of interviews regarding the facilities and infrastructure of the PKPR program at the West Lingkar Health Center revealed an examination and counseling room for adolescents who had no symptoms of illness after the health examination. These results were following the statement of research informants as follows:

"The activities are carried out outside and inside the building. Available facilities are examination rooms and counseling rooms that can be used if no symptoms of illness are found, counseling will be done in the provided room" (Informant 1).

"PKPR implementation is undertaken outside and inside the building, usually going to schools in the working area of the health center, while inside the building there is a room for counseling" (informant 3).

\subsubsection{Sources of PKPR Funds}

Based on the interviews, it was known that the operational costs of implementing the PKPR program came from BOK funds, but these funds were only for the transportation of officers, while funds for the procurement of tools and activities did not yet exist. This result aligned with the following statement:

"Funds for the PKPR program come from health operational assistance funds (BOK). However, only transportation funds for officers but the procurement of equipment and other activities do not yet exist, health center operational 
funds" (Informant 1).

"PKPR activities already have funds from the center for health operational assistance funds. Funds are available only for transportation, but for the procurement of equipment, there is no assistance at least from the operational funds of the health center" (Informant 2).

\subsubsection{Implementation of PKPR}

The implementation of the PKPR program at the West Lingkar Health Center has been doing since 2010 inside the health center building, and then in 2018, it was carried out outside the health center building, especially in schools. The service is open every day following service working hours based on the 2014 PKPR guidelines. According to the following statement:

"The PKPR program holds outside and inside the building. Activities inside the building are conducted at the health center, while outside our building, we go to schools, SMA Sint Corolus and SMAN 7 and junior high schools, which are located in the work area of the health center. For activities outside our building, it has been started since 2018 due to adjustments." (Informant 1).

The implementation of PKPR in the building had an administration flow. Patients or adolescents who seek treatment at PKPR should attain directly to the West Lingkar Health Center with registration and medical records. They would get examinations as needed, then be directed to the service of $\mathrm{MCH}$ (Maternal and Child Health). If the teenager experienced psychological problems during the examination and tended to have adolescent health problems, they would be directed to the PKPR section.

As for teenagers or patients who only needed PKPR services immediately chose PKPR services at the initial registration stage, all patients or adolescents who have been given counseling can go home immediately. However, if the teenager needed further action, it can be continued the next day according to service opening hours. The activities in the building were in the form of counseling and education related to the problems faced by adolescents with the face-to-face method by health workers who are also in charge of the PKPR program assisted by health workers in other fields. As stated by the person in charge of PKPR as follows:

"Usually counseling is carried out after the teenager has had an examination and the teenager tends to have psychological problems" (Informant 1).

Activities outside the building, especially in school, are done twice a year by conducting health counseling, educating and refreshing activities, and forming peer counselors. As the following statement:

"IEC services for adolescents have been undertaken twice a year in August and October, and refreshing activities for adolescents were also conducted to form peer counselors" (Informant 1).

"For the implementation of PKPR, outside the building, we help provide counseling to schools such as nutritional education, if inside the building it is directly handled by the PKPR PJ" (Informant 2).

"Yes, there is PKPR socialization from the health center. I am a peer counselor. I was trained and then they asked about teenagers that I should answer" (Informant 4).

"I know there is PKPR when the health center officers come for counseling" (Triangulation 1).

\subsubsection{PKPR Services}

The results showed that the implementation of the PKPR program followed the national standards under the 2014 PKPR guidelines. The PKPR National Standards were made by the Ministry of Health of the Republic of Indonesia in 2014. The PKPR activities are as follows: 
1) Counseling services

Provided counseling services to all adolescents who required counseling with PKPR officers. The interview results with the person in charge of PKPR said that the West Lingkar Health Center had implemented counseling services for adolescents face-to-face according to the needs of adolescents so that there was no time limit.

Some teenagers had difficulty telling their problems, so the officers invited them to work together at the health center for a few days. Severe cases required more time than the maximum limit, then the counseling officer or psychologist asked the teenager to come on another day to continue the consultation. The health center has been implemented following the Standard Operating Procedures (SOP) for PKPR activities, and the health center also provides health service facilities for PKPR activities in the form of a youth counseling room. According to the following statement:

"Counseling services are not limited because every teenager needs a different time to share their problems. There was once a teenager whom we asked to come back here again. Adolescents need a one-time approach to counseling. So the time will not be limited, according to the needs of the youth, it depends on the problems they face and the condition of the teenagers to usually tell what they are facing" (Informant 1).

PKPR activities outside the building during the Covid-19 pandemic were temporarily postponed, but activities inside the building, such as counseling services, were still carried out following the working hours of the health center while still adhering to health protocols. According to the following statement:

"During this pandemic, there are no more activities outside the building, school children are also on holiday, but activities at the health center are still open every day following the working hours of the health center while still complying with health protocols" (Informant 1).

2) Coaching

Conduct coaching and forming of peer counselors in schools in the working area of the health center. Three schools have been trained, including SMP and SMA: SMP Negeri 08, SMA Negeri 7, and SMA Sint Coroulus. The frequencies of coaching communication, information, and education (KIE) outside the building were managed twice a year, which was held twice in each school. In addition, counseling and regular health checks were done at the school. Meanwhile, youth counseling was done in the health center building. Each teenager is given educational information on adolescent health problems and health materials following the 2014 national standard guidelines. This education is following the implementation in the field. This was evidenced by the results of researcher observations and documentation of activities outside and inside the building. For junior high school children's activities, counseling was conducted on adolescents' preparation for their first menstruation or menarche. Per the following statement:

"The implementation of IEC outside the building, in schools located in the working area of the health center, we have also carried out coaching, there are already peer, counselors. KIE is done after an inspection or data collection related to the extension material that will be delivered later" (Informant 1).

"There is guidance from the health center, two to three times per semester" (Informant 4) 
Peer counselors and youth was participating in PKPR stated that PKPR activities had been managed, such as forming peer counselors and health counseling from the West Lingkar Health Center. The statement was as follows:

"There was a formation of peer counselors, and we were chosen to continue to follow the counseling. We were only taught to become peer counselors" (Informant 4).

"Yes, at that time, as I recall, I attended counseling on dental health" (Triangulation 1)

The results of interviews with adolescents obtained information related to adolescent health. Materials and materials for administering IEC under the service package and according to the needs of adolescents, the results of previous observations made by health workers are presented in power points, videos, leaflets. The methods used for IEC services for adolescents were interviews and questions and answers. By the following statement:

"given an explanation of the extension (Informant 4).

"We learned about adolescent health, from counseling conducted by the health center" (Triangulation 1)

3) Peer Counselor Training

In the guidelines, health centers must train peer counselors at least $10 \%$ of the total number of students in the target schools. The interview results stated that peer counselor training had been held at the Lingkar Barat Health Center, which was undertaken in schools and fostered by the PKPR team at the West Lingkar Health Center. Peer counselors also confirmed that the health center had conducted peer counselor development.

Supported by data on the number of PKPR targets are adolescents in the working area of the West Lingkar Health Center, including 1,474 adolescents aged 10-14 years and 1,763 adolescents aged 15-19 years. The number of cadres or peer counselors is 90 teenagers in the three target schools. According to the statement as follows:

"It has been done, the formation of peer counselors" (Informant 1).

"There are peer counselors. We were told that there was the formation of peer counselors, we were facilitated and given training. There are also activities from the health center providing guidance such as a refreshing to the beach, the health center providing share education" (Informant 4).

\subsubsection{Recording and Reporting of PKPR}

The results of interviews conducted with informants for recording the results of counseling activities and cases of adolescent problems have been carried out by the person in charge of PKPR and reported every two to three months to the health office at the end of the year to the Bengkulu City Health Office which was then reported to the Health Office of Bengkulu City. Provincial Health Office. The results of the report were proposed to find solutions to these problems. The Health Office will instruct the person in charge of PKPR to do socialization activities such as health education in accordance with the results of the report.

The Bengkulu City Health Office receives reports from the health center about implementing PKPR every two to three months, including visit reports. This report is following the informant's statement, as follows: 
"Always record the results of counseling, continue with adolescent problems, and the results are reported to the health office every two or three months depending on the number of records" (Informant 1).

\subsubsection{Monitoring and Evaluation of PKPR Implementation}

The results of interviews regarding monitoring and evaluation of the implementation of the PKPR program have been optimally running because they are carried out every year. Monitoring and evaluation were done annually, which will then be discussed and followed up if there were deficiencies. According to the following statement:

"I report the results of counseling every two or three months to the Health Office. Follow-up actions such as the high smoking rate among teenagers, we were asked to make counseling activities related to the problem. At the school level, we are asked to assist if the peer counselor cannot solve the problem for personal counseling or counseling." (Informant 1).

\subsection{Discussion}

\subsubsection{Human Resources PKPR}

Human Resources (HR) PKPR activities have been written in a Decree (SK) in collaboration with health workers in specific fields who assist in PKPR activities. However, this program still lacks human resources because those who become an officer for PKPR are only those who doubles as the person in charge assisted by other health workers such as doctors, nurses, and officers in their respective fields of expertise as nutrition.

The implementation of the PKPR program must have a PKPR team because the program cannot be run alone by the person in charge of the program [7]. The human resources in question are Health Human Resources, which the entire team or PKPR implementing officers who have the skills and knowledge to provide health services and assist adolescents in solving adolescent health problems [8].

The PKPR implementing team includes doctors, nurses, midwives, nutritionists, psychologists, pharmacists, and other supporting health workers. The attitude of the PKPR team is one of the reasons for teenagers to take advantage of youth care health services at Pukesmas. The attitude of service providers who did not understand and tended to judge adolescents made adolescents reluctant to take advantage of PKPR services at the health center. Teenagers need attentive officers, listen to their complaints, and not scold or look down on teenagers [9].

\subsubsection{PKPR Training Interview}

Results stated that special PKPR training had been provided but only for those in charge of PKPR. Meanwhile, other officers have not been given training. The training provided to the person in charge of PKPR is about health services for adolescents, especially counseling services and the formation of youth counselors, especially in the target schools. The training was also conducted for the target school students to become peer counselors.

The team's success in providing health services to adolescents through the PKPR program will improve the quality of health services and increased adolescent satisfaction. Education and training for the PKPR implementation team are also necessary to improve the knowledge, skills, and expertise of health workers so that the performance of health workers will increase. The role of peer counselors in the PKPR program is needed to assist health center officers in providing counseling services to adolescents, especially outside the building and outside operating hours [10].

\subsubsection{PKPR Facilities and Infrastructure}

Implementation of PKPR activities in the building, the health center has provided 
facilities for teenagers who need counseling in a discussion room for problems that teenagers face so that they are more open to telling their problems.

A specific space is needed in providing personal care for adolescent patients to discuss their problems more openly [11]. The availability and functioning of infrastructure are used to meet the needs and privacy of youth. To provide more personal situation and ensure the confidentiality of adolescents during counseling, this is important for the health center to provide a particular counseling room that is separate from other treatment rooms that do not allow other staff to see or hear the ongoing consultation [12].

\subsubsection{Sources of PKPR Funds}

The results of interviews with the person in charge obtained information on the implementation of the PKPR program from the Special Operational Assistance (BOK) fund, but the funds are only for the transportation of officers. In contrast, funds for the procurement of equipment and activities did not have special funds and are still limited, so that the activity funds such as holding counseling were taken from the operation of the health center.

These results aligned with other studies that state that the source of funds in implementing the PKPR program at the Muntilan I Health Center comes from the BOK [13]. BOK is assistance from the Central Government to Regional Governments to improve access and quality of public health services, especially promotive and preventive in the working area of the Health center [14].

\subsubsection{Implementation of PKPR}

Implementation of PKPR began in 2010 inside the building, while activities outside the building, such as PKPR activities in schools, started in 2018 in the three target schools. The activities in the building, such as counseling for teenagers who needed services with face-to-face methods. Counseling was carried out by the person in charge of the PKPR program, assisted by health workers in other fields in providing education regarding the problems faced by adolescents.

The implementation of PKPR is still limited to target schools, and there was no socialization for teenagers around the health center, especially for teenagers who have dropped out of school. Related to this, the person in charge has also explained that there are still difficulties in data collection efforts, so that the implementation of PKPR has not run optimally because not all youth in the working area of the health center have received information related to PKPR. The collaboration that has been carried out has not been as expected because it has not been carried out in collaboration with youth organizations and groups that accommodate youth, only with schools and the National Anti Narcotics Agency.

PKPR provides promotive, preventive, curative, and rehabilitative services to adolescents, which must be provided as a whole in all places where youth services will be carried out. PKPR aims to encourage providers, especially health centers, to provide comprehensive health services, according to the needs of adolescents who want confidentiality, to be recognized, respected, and involved in the planning, implementation, and evaluation of activities [15].

The existence of a PKPR Team is a must in carrying out the PKPR program because the PKPR program cannot run alone and is carried out by the Youth Responsible Person himself at the health center. Therefore teamwork is needed. The role of health workers in fulfilling the implementation of the PKPR program is as a promoter or health extension expert at the health center [7].

\subsubsection{PKPR}

Services adolescent care health services have national standards following PKPR guidelines. The PKPR guidelines at the health center run well and correctly. The PKPR National Standard was made by the Ministry of Health of the Republic of Indonesia in 2014. The services provided were in the form of counseling, coaching in three target 
schools located in the West Lingkar Health Center's work area, face-to-face adolescent counseling for adolescents.

10-19 years old, and has established peer counselors who aim to help problem-solve adolescents in the target schools. Young people needed to know that PKPR services are not just counseling at schools but can also be done at the health center. Activities in the form of IEC services, counseling, clinical medical services, both supporting and referral, Healthy Life Skills Education (PKHS), and peer counselor training from PKPR officers [10]. A study stated that there is a need for promotion in providing service information through electronic media, print media, and the environment, such as collaborations and events [16].

PKPR program services are intended for all youth aged 10-19 years, both at school and in the community. Many activities are carried out in the PKPR program, such as counseling, counseling, youth screening, school development and peer counselors, and others [17]. In line with other studies, adolescents participate in PKPR activities such as peer counselor training, health checks, treatment, counseling, and counseling [18].

PKPR activities in the form of counseling and coaching cadres provide information and health education for adolescents who need it and help add insight into adolescent health [19].PKPR services are in the form of health checks, counseling, and counseling aimed at increasing the knowledge and skills of adolescents in the prevention of health problems. Information related to PKPR in counseling activities can affect adolescent knowledge. Adolescents must be aware of the existence of PKPR as a forum to overcome adolescent health problems. Health services in PKPR at health centers are carried out by health workers [20].

Guidance should be doing at a minimum of one public school or religion-based school in one year. The guidance is to carry out IEC at least twice a year. IEC is carried out outside the building and inside the building. Activities outside the building include counseling and periodic health checks at the school. KIE in the building is carried out with youth counseling activities. Materials and materials for administering IEC are following the service package, and according to the needs of adolescents, the results of previous observations made by health workers are presented in power points, videos, leaflets. The methods used for IEC services for adolescents are interviews and questions and answers. The health center has also carried out stimulating activities for teenagers.

The Rangkah Health Center has provided supporting facilities and infrastructure for implementing PKPR activities, including IEC media, data cabinets, and health measures such as body height and body weight, which is stated in line with the results of other studies. The need for PKPR health center infrastructure facilities can be assisted by the City Health Office in accordance with the PKPR Management Guidelines to complement health facilities for PKPR activities [7].

The service to train peer counselors at the West Lingkar Health Center has been conducted according to the $10 \%$ standard. Ninety cadres or peer counselors have been formed covering three target schools located in the working area of the West Lingkar Health Center Bengkulu City. Then there is cadre stimulating activities.

Youth program outside the building varies among Primary Health Care (PHC), which is in line with the results of other studies. Most of the PHCs have implemented health education programs in the schools covered in their area. Most PHCs also have programs for peer training as health counselors. Some PHCs have youth training programs to volunteer in keeping the environment free from mosquito larvae [11].

In line with other research on the analysis of the implementation of the PKPR program at the Palembang City Health Center, it explained that the implementation of PKPR, in general, has been carried out well, this can be seen from the formation of peer counselors and counseling in schools and has been budgeted annually. Officers have carried out services following existing guidelines [21].

Refreshing youth health cadres is a training activity for new cadres every year to replace those previously trained cadres. This activity aims to form youth health cadres in schools to replace the previous cadres. The role of cadres is very much needed because cadres are community workers who are closest to the surrounding community $[22,23]$. 


\subsubsection{Recording and Reporting on PKPR Implementation}

The recording of the counseling results and cases of adolescent problems has been carried out by the person in charge of PKPR and reported every two to three months to the health office. Recording this report is important to monitor the implementation of the activities that have been carried out. In line with the research results, three health centers found guidelines and formats for recording reporting, but from the observations, only one health center sent a report on the results of PKPR activities at the health center, including case visits [23].

In line with the study results, that recording is carried out by the program implementing coordinator, and reporting is carried out every month to the City Health Office (DKK) [18]. Likewise with other studies that recording and reporting have been carried out by the Beringin Raya Health Center. The recording is carried out at each implementation of PTM Posbindu activities [24,25].

\subsubsection{Monitoring and Evaluation of PKPR Implementation}

Monitoring and evaluation of the implementation of PKPR in the work area of the West Lingkar Community Health Center are carried out at the Bengkulu City Health Office once a year, which will then be discussed and followed up if there are deficiencies. The implementation of PKPR has been carried out by the PKPR team, which is written in the SK. The PKPR program carries out activities inside and outside the health center

Building and has already fostered schools and formed peer counselors. The flow of services has been adjusted to the health services needed by adolescents. The health center has provided supporting facilities such as counseling rooms, counseling, and health checks for adolescents. The health center has collaborated with related sectors in conducting counseling, such as in nutrition and the National Narcotics Agency.

Evaluation of PKPR implementation is based on the 2014 PKPR National Standards issued by the Ministry of $\mathrm{RI}$, namely, looking at the achievement of standards for implementing PKPR programs or activities at the health center level. This PKPR National Standard regulates five aspects, namely health human resources (Knowledge and Competence of Officers, Youth Counseling Services), Health Facilities (Service Packages, Procedures, Management and Service Flows), Youth (IEC Activities), Networks (Stakeholder Mapping, Participation Youth), Health Management (Advocacy, Recordkeeping, and Reporting and Referrals) [5].

Program evaluation was carried out annually together with other programs. Evaluation was done by looking at each program's monthly report. The monthly report was recapitulated into an annual report and seeing any problems. The annual report for each program was adjusted to the achievement of program targets based on standards from the Health Office. Programs that did not reach the target will be analyzed and given to the program director $[26,27]$.

Mini-workshop as an effort to communicate and evaluate PKPR to improve the running of the program [21]. In line with a study that monitoring was carried out by the head of the health center, evaluation was carried out at the end of every year with other health center programs, and monitoring from the Jepara DKK was carried out every year [18].

Other studies also state that the PKPR program was monitored and evaluated. Types of monitoring and evaluation of the PKPR Program. The evaluation was carried out by the head of ICSDH 2018 - International Conference on Social Determinants of Health 58PHC and also the Jakarta District Health Office. It is done every month and every three months. Monthly evaluations were carried out by PHC staff, while 3-month evaluations involve other sectors such as the education sector and government [11]. Evaluation is important to see the existing problems and the achievements of an activity $[29,30]$.

\section{Kesimpulan}

Based on the research above, it can be concluded that the implementation has followed PKPR guidelines, but overall, it was still not optimal. There was no regular socialization of 
PKPR, especially for teenagers who do not attend school. Therefore, the researcher recommends that PKPR socialization be held regularly, especially for not in-school teenagers, and expand inter-sectoral collaboration related to activities.

\section{References}

1. RISKESDAS. Laporan Nasional Riskesdas 2018. Badan Penelitian dan Pengembangan Kesehatan. Jakarta; 2018.

2. Kemenkes RI. Profil Kesehatan Indonesia Tahun 2019. Kementerian Kesehatan RI. Jakarta; 2020.

3. Andriyani J. Peran Lingkungan Keluarga Dalam Mengatasi Kenakalan Remaja. At-Taujih Bimbing dan Konseling Islam. 2020;Volume 3(Nomor 1):Hal: 86-98. doi: http://dx.doi.org/10.22373/taujih.v3i1.7235

4. Zulkhairi, Arneliwati SN. Studi Deskriptif Kualitatif: Persepsi Remaja Terhadap Perilaku Menyimpang. J Ners Indones. 2018;8(2):145-57. doi: http://dx.doi.org/10.31258/jni.8.2.145-157

5. Avilla T. Gambaran Pelaksanaan Pelayanan Kesehatan Peduli Remaja ( PKPR) di Puskesmas Dupak Surabaya Description of Implementation Health Care Services Adolescent (PKPR) at Puskesmas Dupak Surabaya. J Promkes. 2019;Volume 7(Nomor 1):78-87. doi: http://dx.doi.org/10.20473/jpk.V7.11.2019.78-87

6. Puskesmas. Laporan Kegiatan Konseling Remaja Puskesmas Lingkar Barat, 2020. Puskesmas Lingkar Barat. Bengkulu; 2020.

7. A'yun Lu'lu Qurrotu QMB. Evaluasi Pelaksanaan Program Pelayanan Kesehatan Peduli Remaja (PKPR) di Puskesmas Rangkah. J Keperawatan Muhammadiyah. 2019;Edisi Khus(2019):232-8. doi: http://dx.doi.org/10.30651/jkm.v4i2.2025

8. Meilan. Kesehatan Reproduksi Remaja: Implementasi PKPR Dalam Teman Sebaya. Malang: Wineka Media; 2018.

9. Kristina Yunita. Faktor-faktor yang Mempengaruhi Pemanfaatan Pelayanan Kesehatan Reproduksi Remaja di Kota Jayapura. J Biol Papua. 2017;Volume 9(Nomor 2):63-73. doi: https://doi.org/10.31957/jbp.115

10. Dewi, Putri Sari Nugrahaning, Zahroh Shaluhiyah CS. Analisis Implementasi Pelayanan Kesehatan Peduli Remaja (PKPR) di Puskesmas. J KESMAS (Kesehatan Masyarakat) $\begin{array}{lllll}\text { Khatulistiwa. 2020; Volume 7(Nomor } & 3 \text { ): } \mathrm{Hal} & \end{array}$ http://dx.doi.org/10.29406/jkmk.v7i3.2146

11. Iram Barida Maisya, Mochamad Iqbal Nurmansyah MS. An Evaluation of Youth Care Health Program ( PKPR ) in Public Health Center in Jakarta, Indonesia. ICSDH. 2019; (Icsdh 2018):Halaman: 56-60. doi: https://www.scitepress.org/Papers/2018/83805/83805.pdf. http://scitepress.org.

12. Mazur A, Brindis CD, Decker MJ. Assessing youth-friendly sexual and reproductive health services: A systematic review. BMC Health Serv Res. 2018;Volume 18(Nomor 1):Halaman 1-12.

doi: https://bmchealthservres.biomedcentral.com/articles/10.1186/s12913-018-2982-4

13. Anisah S N. Program Pelayanan Kesehatan Peduli Remaja di Puskesmas. J Public Heal Res Dev. 2020;Volume 4(Special 4):Halaman: 846-854. doi: https://doi.org/10.15294/higeia.v4iSpecial\%204.37007.

14. Permenkes RI. Petunjuk Teknis Penggunaan Dana Alokasi Khusus Nonfisik Bidang Kesehatan Tahun Anggaran $2020 . \quad 2019$. https://peraturan.bpk.go.id/Home/Details/138676/permenkes-no-86-tahun-20194.37007

15. Muthmainnah $M$, Nurmala I, Siswantara $P$, Rachmayanti RD. Implementation of adolescent health programs at public schools and religion-based schools in Indonesia. $J$ Public health Res. 2021; doi: https://doi.org/10.4081/jphr.2021.1954

16. Oktarianita, Henni Febriawati DK. Hubungan Strategi Bauran Pemasaran Dengan Loyalitas Pasien Rawat Jalan di RSUD Dr. M. Yunus Provinsi Bengkulu. Avicenna. $\begin{array}{llll}\text { Volume } & \text { 15(Nomor } & 3 \text { ):Halaman: 198-205. }\end{array}$ 
https://doi.org/10.36085/avicenna.v15i3.978

17. Novi Afrianti, Mudatsir TT. Analisis Implementasi Program Pelayanan Kesehatan Peduli Remaja ( PKPR ) Implementation Analysis of Adolescent Health Care Service Program at Public Health Centres. J IImu Keperawatan. 2017;5(2):2-17. doi: http://jurnal.unsyiah.ac.id/JIK/article/view/10544

18. Amieratunnisa Aniesah I. Implementasi Program Pelayanan Kesehatan Peduli Remaja. $J$ HIGEIA. 2018;Volume 2(Nomor 1):Halaman: 69-79. doi: https://journal.unnes.ac.id/sju/index.php/higeia/article/view/18466

19. Kenti Friskarini HSPM. Implementasi Program Pelayanan Kesehatan Peduli Remaja (PKPR) di Tingkat Puskesmas DKI Jakarta. J Ekol Kesehat. 2016;16(1):66-75. doi: http://journal.unnes.ac.id/sju/index.php/higeia.

scholar.google.co.id/citations?user=eLOdfwOAAAAJ\&hl=en. p-ISSN 2541-5581 e-ISSN 2541-5603

20. Sartika Andry, Oktarianita P. Penyuluhan Terhadap Pengetahuan Remaja Tentang PKPR. J Telenursing. Volume 3(Nomor 1):Halaman: 171-176. doi: https://doi.org/10.31539/joting.v3i1.2192

21. Tiara Pratiwi, Sri Handayani $\mathrm{Y}$, Isnaeni. Analisis Implementasi Program Pelayanan Kesehatan Peduli Remaja (PKPR) di Puskesmas Kota Palembang. J Penelit Kesehat Suara Forikes. 2018; Volume 9(Nomor 3):Halaman: 197-203. doi: http://dx.doi.org/10.22435/jek.v15i1.4957.66-75

22. Noor MS, Sari AR, Akbar Agustriyanto R, Norwinardi R, Agustina D, Rahmaniah E, et al. Role of Cadre In Improving Knowledge and Attitude of Chronic Energy Deficiency on Teenagers In Mali-Mali Village, Banjar Regency, South Kalimantan, Indonesia. Open Access Maced J Med Sci. 2021;9:145-9. doi: https://doi.org/10.3889/oamjms.2021.5664

23. Fadrianti, Fika Maulani ES, Darmawan. Sumber daya manusia dan manajemen organisasi dalam pelaksanaan upaya kesehatan masyarakat di dua kecamatan di Jakarta Timur. Ber Kedokt Masy J Community Med Public Heal. Volume 34(Nomor 6):Halaman: 221-229. doi: https://doi.org/10.22146/bkm.34736

24. Sukaedah Een S. Analisis Penerapan Standar Nasional Pelayanan Kesehatan Peduli Remaja (PKPR) Pada Puskesmas PKPR di Kabupaten Lebak Tahun 2016. J Med. Volume 4(Nomor 1):Halaman: 23-33. doi: https://doi.org/10.36743/medikes.v4i1.67

25. Husniah N, Widodo S. Implementation of Integrated Village NCD Prevention Post (POSBINDU) in Senior High SchooL. J Heal Educ. 2019;4(2):57-60. doi: https://doi.org/10.15294/jhe.v4i2.34084

26. Oktarianita, Wati, N. \& Febriawati H. Persepsi Peserta Posbindu Ptm Tentang Pelaksanaan Kegiatan Pos Pembinaan Terpadu Penyakit Tidak Menular (Posbindu PTM) Di Wilayah Kerja Puskesmas Beringin Raya Kota Bengkulu. J IIm Avicenna. Volume 15(Nomor2):Halaman:

https://doi.org/10.36085/avicenna.v15i2.988

27. Oktarianita, Nopia Wati HFA. An Analysis on the Implementation of Posbindu PTM Program at Beringin Raya Community Health Center Bengkulu. Dis Prev Public Heal J. Volume 15(Nomor 1):Halaman: 1-13. doi: https://doi.org/10.12928/dpphj.v15i1.2841

28. Delita, Ayu, Rifai Achmad L era elvi. Analysis Of Health Services Care Utilization For Youth (PKPR) In Working Areas Langsa Health Centre 2020. J Healthc Technol Med. 2020;6(2):1127-41. doi: https://doi.org/10.33143/jhtm.v6i2.1159

29. Suciana S, Hasnita E, Nurhayati. Evaluasi Pelaksanaan Program Kesehatan Peduli Remaja (PKPR) di Sekolah Menengah Atas Kota Bukittinggi Tahun 2017. Hum Care J. 2019;4(2):76. doi: http://dx.doi.org/10.32883/hcj.v4i2.156

30. Febriani A. Evaluasi Keberhasilan Program Pelayanan Kesehatan Peduli Remaja ( PKPR ) Tingkat Dasar Di Puskesmas Kota Bukit Tinggi Tahun 2016. J Midwifery. 2019;3(2):55-9. doi: http://jurnal.univrab.ac.id/index.php/jomis/article/view/821 